\title{
The Relevance of Learning Theories in Adult and Non-Formal Education
}

\author{
Francis O. Olaniyi \\ Department of Arts Education, Faculty of Education, Adekunle Ajasin University, Akungba-Akoko, Ondo State, Nigeria \\ francisolaniyi@yahoo.com
}

\section{Doi:10.5901/jesr.2015.v5n1p261}

\begin{abstract}
The purpose of this study is to examine the relevance of learning theories to adult and non-formal educational programmes. Adult and non-formal education is a kind of educational activities targeted at those who are regarded as adults by the society they belongs with the aim to developing their socio-economic and political status, so they can contribute their quota to the development of their immediate environment and society at large. The advanced nature of adult learners makes their learning activities to be more different from the children learning environment. This is because of maturity, bulk of experiences and sense of professionalism they bring to learning environment that make facilitators sees them as partners in progress. Efforts are made in this study to discuss the concept of adult and non-formal education as well as various learning theories that must be valued in adult learning environments. The paper, therefore, conclude that facilitators and organizers of adult education programme must ensure the strict application of these learning theories for effective adult teaching and learning environment.
\end{abstract}

Keywords: Adult and non-formal education, learning theories, facilitator, adult learners, development, lifelong learning

\section{Introduction}

Adult and non-formal education has become a significant component of education in this $21^{\text {st }}$ Century. In fact it is recognised as one of the basic tools for making sustainable development a reality in any society. The term 'education' in the broad sense is not only a pedagogical one punctuating down to the basic meaning of the term; it means to plunge a man's body, mind and soul of ignorance. It enhances an individual's personality and provides him confidence to reach out to the world. Thus, education that would make man to be relevant and functional in a dynamic society must be lifelong in nature. This means that there must be provision for education at every facet of man's development which is only possible through adult and non-formal education. The role of adult and non-formal education in ensuring that all people in the society are educationally catered for cannot be underestimated. This is why various developmental agencies and Organizations are devoting resources to its promotion, especially in the developing nations of the world.

Nyerere (1979:49-52) who advocates education for self-reliance sees education as development. To Nyerere, development is transformative in that education develops man who transforms his society. Man is biologically and physically unfinished requiring his life to be an unending process of completion and learning. This realization of the need for educational provisions throughout life has led different bodies and institutions to coin out different terms for it. These include continuing education, recurrent education, non-formal education, functional education, remedial education and lifelong education, among others. Each of these terms could be used interchangeably with others. However, there could be some special emphasis between one and another. For instance, all agree that education should be a cafeteria system where the appetite of everybody should be catered for at any point in time, be it for intellectual, vocational or recreational purposes.

Continuing education emphasizes more on the provisions for any purpose after the cessation of the formal schooling. Recurrent education, on the other hand, is a conception of the optimum disposal of knowledge resources and learning facilities, for the maximum benefit of society (Houghton, 1974:6) while remedial education is often targeted at people or group of people with the purpose of filling a vacuum which lack of knowledge of a particular task, function or field has created in their lives. But lifelong education, the background of which was laid by the report of the World Survey of Education Chaired by Edgar Faure (1972), includes all that other terms mean but emphasizes on the integration of formal, non-formal and informal educational provisions as each contributes to the overall educational acquisition by an individual.

Some kernels of lifelong education emphasize, according to Cropley (1979:3), that education should: last the whole life of each individual; lead to the systematic acquisition, renewal, upgrading and completion of knowledge, skills, 
and attitudes made necessary by the constantly changing conditions in which people now live; have as its ultimate goal promotions of the self fulfilment of each individual; be dependent for its successful implementation on people's increasing ability and motivation to engage in self-directed learning activities; acknowledge the contribution of all available educational influence, including formal, non-formal and informal education.

However, in doing justice to this study, exploring some theories of learning which are relevant to adult and nonformal educational environment would be considered necessary in view of dynamism of the programme and the target participants who are adults with a sense of maturity and responsibilities. It is on this note that this study tends to look at the importance and the application of these theories to adult and non-formal education with a view to determining the extent at which these theories can help in actualizing the overall goal and objectives of adult learning environment.

\section{Adult and Non-formal Education}

Adult and Non-formal education is one of the concepts that does not submit to a universal definition. The reason is not far-fetched, the nature and scope of adult education varies from one society to another. It is necessary however, to look at some definitions given by some scholars for clarity of purpose. UNESCO (1997) submits that adult education denotes the entire body of ongoing learning processes, formal or otherwise, whereby people regarded as adults by the society to which they belong develop their abilities, enrich their knowledge, and improve their technical or professional qualifications or turn them in a new direction to meet their own needs and those of their society.

Furthermore, Anowor, Ezema and Umezuluike (2001) described adult education as a field of study as deep as life itself. Afrik (2000) divided the concept adult education into two broad categories: traditional and indigenous adult education and contemporary adult education. Fafunwa (1974) noted that traditional adult education is aimed at producing an individual who is honest, respectable, skilled, cooperative and who conforms to the social order of the day. Okedera (1996) on his part, referred to contemporary adult education as all-available educational activities organised for adults without legal compulsion while Radcliffe and Colleta (1989) subscribe to the view that non-formal education is any organised educational activity outside the established formal system: whether operating separately or as an important feature of some broader activity that is intended to serve identifiable learning clientele and teaching objectives. Bockarie (1991) and UNESCO (2001) concluded that adult education is linked with the intention to improve personal living whether in social or in economic terms, and with national development as a whole.

The overall objective of the Adult and Non-formal Education strategy is "Ensure, in partnership with the civil society, that out-of-school children, youth and adults have access to quality basic learning opportunities, especially girls, women, disadvantaged groups and nomads, with a view to improve the literacy level and reducing the backlog of out-ofschool children ; thus contributing to the creation of a lifelong learning society, improvement in people's livelihood, and to an increased awareness and prevention of HIVIAIDS."

Adult learning in developing nations, for example Nigeria covers literacy, vocational technical education, open apprenticeship, labour education, continuing education for remedial purposes (early school leavers) and professional competence building and upgrading of skills and status. However, the major areas of concerted Government efforts before and especially after the 1997 Hamburg declaration includes: basic literacy, post literacy, women's education, rehabilitation education, gender equity and equality of educational opportunities. New dimensions in adult learning following the1997 Hamburg declaration are: peace and stability education, citizenship education, reproductive and sexuality education, among others.

Moreover, Malcolm Knowles (1984), while explaining the concept of andragogy, identified six principles of adult learning which facilitators must take note of for effective adult learning environment. In explaining these principles, Knowles is of the opinion that:

i. Adults are autonomous and self-directed. This means they like to direct their own learning, to be actively involved in learning and work around their specific interests and personal goals. Generally, they like to take on leadership roles.

ii. Adults bring life experiences and knowledge to learning experiences. This may include work-related activities, family responsibilities, and previous education.

iii. Adults are goal oriented. There is a particular target they want to meet and this influence their decision in joining literacy classes for the quick attainment of that purpose.

iv. Adults are relevancy-oriented. They need to see a reason for learning something. When they see the applicability they also see the value in the experience. Theory needs to be related to practical experiences.

v. Adults are practical. They like to be able to apply their knowledge. Clinical education settings are the ideal 
place for them to do this, hence most students simply love to be out on practicum.

vi. Adult learners like to be respected. They bring considerable life experiences to their clinical placements. They like to be treated as equals, to voice their own opinions and to have a role in directing their own learning.

However, the aforementioned principles cannot be respected without the application of relevant principles of adult and non-formal education and this lead us to the next discussion.

\section{Learning Theories Related to Adult and Non-Formal Education}

There are relevant learning theories which are applicable to adult and non-formal education environment. These theories, as discussed by Cowlan, J., Grawbowski, S., and Smith, K. (2010), when applied would undoubtedly stimulate the interest of adult learners to learning environment. They include:

\section{Action Learning Theory}

Action learning is defined as an approach to working with, and developing people, which uses work on a real project or problem as the way to learn. Participants work in small groups or teams to take action to solve their project or problem, and learn how to learn from that action. A learning coach works with the group in order to help them learn how to balance their work, with the learning from that work (O'Neil, 2000).

Action learning is a commonly used term in many discussions regarding adult learning in a variety of business settings. Action learning has been compared with project work, learning communities and various forms of simulation used in management development.

Action Learning: How it works: The first part of action learning is creating action groups based on programmed learning, "the expert knowledge" and learning or real world experiences. These are small groups, generally consisting of 3 or 4 people. Emphasis is placed on diversifying these small groups so that each group is best equipped to contribute to the learning community. A learning coach is designated for each group. Together, the learning coaches also form a group. From there, a project group leader is chosen. Both the project group leader and the learning coaches act as organizers, facilitators and overall motivators for the action groups (O'Neil, 2000). Action learning involves learning from experience through reflection and action with the support group. It is important that the groups remain constant and create time, interest and opportunity to establish themselves over a solid time period (Wade, 1999).

\section{Experiential Learning Theory}

Experiential learning is a learning theory that is learner-centered and operates on the premise that individuals learn best by experience. A good way to describe this theory is "learning by doing". Experiential learning thus has the learner directly involved with the material being studied instead of just thinking and talking about that material.

Experiential learning is a cyclic process involving setting goals, thinking, planning, experimenting and making decisions, and finally action, followed by observing, reflecting and reviewing. It makes use of participants' own experience and their own reflection about that experience, rather than lecture as the primary approach to learning. Experiential learning theory allows for the generation of understanding and allows for the transfer of skills and knowledge. It involves doing something and discovering what it is like, how it made the learner feel, what it meant to the learner, i.e. experiential learning is their experience and no one else's.

Experiential learning, therefore, is particularly effective in adult education and non-formal education as it addresses the cognitive, emotional and the physical aspect of the learner.

\section{Project Based Learning Theory}

In Project Based Learning, students work in groups to solve challenging problems that are authentic and often interdisciplinary. Learners decide how to approach a problem and what activities to pursue. Here, the learners gather information from a variety of sources and synthesize, analyze, and derive knowledge from it. The learning is inherently valuable because it is connected to something real and involves adult skills such as collaboration and reflection. At the end, the learners demonstrate their newly-acquired knowledge and are judged by how much they have learned and how well they communicate it.

Throughout this process, the facilitator's role is to guide and advise, rather than to direct and manage student 
work.

\section{Self-Directed Learning Theory}

Self-directed learning is an example of informal learning. It is defined as the process in which individuals take on the responsibility for their own learning process by diagnosing their personal learning needs, setting goals, identifying resources, implementing strategies and evaluating the outcomes.

There are three categories involved with self-directed learning: the goals, the process, and the learner. In an adult learning context, the goals are generally self-determined, as is the process. Self-directed learning can be enhanced with facilitation, particularly through providing resources.

Motivation is a key to a successful self-directed learning experience. This is very similar to the motivation that takes place in children during a self-regulated learning experience. Adult Learners are motivated by the opportunity to: gain new skills, knowledge, and attitudes to improve their work performance, improve family life and health, enjoy the arts and physical recreation, participate in a hobby, or simply increase their intellectual capital.

\section{Conclusion}

The right to education is a universal one, which was declared at the floor of UNO in 1948 and since, has been severally adopted by member nations and reemphasized by the United Nations. Adult and Non-formal education is one of the basic keys that open the door of development in this $21^{\text {st }}$ Century. Apart from the opportunity of creating an educational environment supporting all forms of learning for older people, it also gives room for disadvantaged groups in the society (i.e. rural women, orphans, people living with disabilities, prison inmates, etc...) to acquire one skill or the other that would make them to be independent of their own. Because of the dynamic nature of Adult and Non-formal education, it becomes imperative for facilitators and organizers of adult education programmes to apply relevant theories discussed in this paper for successful conduct of adult and non-formal education programme. This will not only create a sense of belongingness in learners, it will also aid the quick attainment of the overall goal and objectives of adult learning environment.

\section{References}

Cowlan, J., Grawbowski, S., and Smith, K. (2010) Adult Learning: Emerging Perspectives on Learning, Teaching and Technology: http://projects.coe.uga.edu/epltt/index.php (retrieved on 19/12/2010)

Cropley, A.J. (1979). "Introduction," (pp.1-6) in A.J. Cropley (ed.), Lifelong Eduaction: A Socktakiing. Hamburg: UNESCO.

Houghton, V. (1974). "Recurrent education," (pp.1-9) in V. Houghton and K. Richardson (eds.), Recurrent education: A plea for Lifelong Learning. London: Ward Lock Educational.

Knowles, M. S. et al (1984) Andragogy in Action. Applying modern principles of adult education, San Francisco:Jossey Bass.

Okedara, J.T. (1980). "The Achievements of 1970/75 and 1978/80 National Development Plans in Relation to Adult Education in Nigeria." West African Journal of Education, 21 (3): 1-4.

Nyerere, J.K. (1979). "The overall educational conception," (pp.17-55) in H. Hinzen and V.H. Hundsdorfer (eds.), Education for liberation and development. Hamburg. UNESCO.

O'Neil, J. \& Lamm, S.L. (2000). Working as a learning coach team in action learning. New Directions for Adult \&Continuing Education, v. 87, p. 43-52.

Wade, S. \& Hammick, M. (1999). Action learning circles: Action learning in theory and practice. Teaching in Higher Education, v. 4, p. 163-179. 